\title{
THE PERFORMANCE OF WILLIAM BILLINGS' MUSIC
}

\author{
Richard Crawford \\ David P. McKay
}

Present-day choristers who have sung the music of the eighteenthcentury American composer William Billings have been amply rewarded. Billings' music is simple to learn and pleasing to sing. His powerful melodic gift, supported by a harmonic sense, gives it an off-center attractiveness that wears rather well with both singers and listeners. The music seems to present few performance problems. The training and proficiency of even moderately experienced choristers are more than adequate for coping with any technical problems the music might present. However, authenticity rather than technical problems represents the chief difficulty here. If one is going to perform Billings' music or music from any other past tradition, one must approach that music on its own terms. One discovers to the best of his ability the music's framework of style, sound, and pace and maintains that framework in performance, so far as present-day realities permit. Fortunately for modern-day performers, in Billings' tunebook introductions he spelled out for his readers those matters that were uppermost in his mind. Often his comments touched on performance; a study of what he wrote about the various aspects of performance will be most helpful to musicians concerned with authenticity.

Readers should not infer that Billings' advice about performance applies to all the music of his contemporaries as well as to his own music. Alone among American compilers of his generation, Billings devoted his publications to his own music, the Music in Miniature excepted. In his three lengthy introductions-to the New-England Psalm-Singer, the Singing Master's Assistant, and the Continental Harmony-he addressed himself to the performance problems he 
considered most important and most likely to cause trouble. The present summary restricts itself to a survey of Billings' own comments about the music he composed.

The first problem in the performance of Billings' music is that his disposition of voice parts is different from the norm. As was typical of Anglo-American psalmodists, Billings set the melody in the tenor rather than the soprano, or treble, as he called it. Billings' music is composed for four voice parts set in open score. The bass is written in bass or $F$ clef, the tenor in treble or $\mathrm{G}$ clef and sung an octave below notated pitch. For the counter, occupying a range slightly lower than the modern alto, Billings uses a $\mathrm{C}$ clef; and the treble, equivalent to the present-day soprano, is written in treble clef. The bass is always sung by men. Apparently Billings also assigned the counter to men and boys, though he never specifically indicated this. Perhaps, since the counter was clearly the least important of the four parts, he did not care who sang it as long as it remained relatively unobtrusive.

In a glossary in the New-England Psalm-Singer he defines treble as "The 3d Octave above the Bass, adapted to Feminine Voices in either Sex." He provided the following explanation of the tenor: "Tenor-The second Octave above the Bass, also the leading or Church Part, and may be set in the $\mathbf{C}$ or $\mathbf{G}$ Cliff, if in the latter it must be sung an Eighth below the Treble." 1 What Billings meant by the last part of this definition is that the tenor, despite sharing a clef with the treble, occupies the range an octave below it because of the natural difference between men's and women's voices. However, in the same collection he recommended octave exchanges and doublings between the two voices.

A Man cannot sing a proper Treb!e without counterfeiting a Woman's Voice, which is very unnatural, and in the Ears of most Judges very Disagreeable: Neither can a Woman sing a proper Tenor without counterfeiting a Man's Voice, which is also unnatural and disagreeable: But a Man may sing a Treble the Eighth below, and a Woman a Tenor the Eighth above, and then they will act upon Principles of Nature, and may make good Music, for every Eighth or Octave in Effect is the same. ${ }^{2}$

Billings advocated not a wholesale, but a limited exchange between tenors and trebles, with some of each singing the other part in their own range. That is surely what he meant when he noted, "every Eighth or Octave in Effect is the same." The treble and tenor parts obviously do not move in octaves, but when each is doubled at the octave the four pitches that usually result resolve themselves down to two.

In the Continental Harmony, Billings explored the subject somewhat more deeply:

Scholar. Pray sir, what is the difference between the Medius and Treble? Master. When a piece of music is set in four parts, if a woman sings the upper part, it is called a Treble, because it is three-fold, or the third octave from the

\footnotetext{
${ }^{1}$ William Billings, New-England Psalm-Singer (Boston: Edes and Gill, 1770), p. 21.

${ }^{2}$ New-England Psatm-Singer, p. 11.
} 


\section{0/JRME}

Bass, but if a man sings it, it is called a Medius, or Cantus, because he sings it an octave below a Treble.

Scholar. Which is the best of these two?

Master. It is sometimes set so, as for one part to be best, and sometimes the other; but in general they are best sung together, viz. if a man sings it as a Medius, and a woman as a Treble, it is then in effect as two parts; so likewise, if a man sing a Tenor with a masculine and a woman with a feminine voice, the Tenor is as full as two parts, and a tune so sung, (although it has but four parts) is in effect the same as six. Such a conjunction of masculine and feminine voices is beyond expression, sweet and ravishing, and is esteemed by all good judges to be vastly preferable to any instrument whatever, framed by human invention.

Scholar. And is it a matter of indifference which part is sung, either Medius, or Treble?

Master. No, for if one part must be omitted, I chuse it should be the Medius, because oftentimes notes in the Treble which are fifths above the Tenor, or Bass, when sung as a Medius, are converted into fourths below. ${ }^{3}$

What is perhaps most significant here is Billings' recommendation that the tenors customarily be divided, that medius and treble "in general . . . are best sung together." There is nothing in the passage to suggest that the same does not apply to the trebles, since six parts are specifically mentioned as "beyond expression, sweet and ravishing." Given all of this dividing of upper parts, it is rather surprising to read that-at least at the beginning of his musical career-Billings' ideal chorus was bottomheavy.

In Order to make good Music, there is great Judgment required in dividing the Parts properly, so that one shall not over-power the other. In most Singing Companies I ever heard, the greatest Failure was in the Bass, for let the Three upper Parts be Sung by the best Voices upon Earth, and after the best Manner, yet without a sufficient Quantity of Bass, they are no better than a Scream, because the Bass is the Foundation, and if it be well laid, you may build upon it at Pleasure. Therefore in order to have good Music, there must be Three Bass to one of the upper Parts. So that for Instance, suppose a Company of Forty People, Twenty of them should sing the Bass, the other Twenty should be divided according to the Discretion of the Company into the upper Parts. . . .4

There is nothing to indicate that Billings or any other singing-master in eighteenth-century America was able to assemble a "singing company" in which basses enjoyed a three-to-one numerical superiority over the other voice parts. In Billings' only school for which the scholars' names were all recorded, his Stoughton singing-school of 1774, the roster reads as follows: "Bass: five males; Tenor: eight males, thirteen females; Counter: five males; Treble: eighteen females; (Total, eighteen males and thirtyone females)."5 That these proportions make a mockery of Billings' ideal

\footnotetext{
${ }^{3}$ Billings, Continental Harmony (Boston: Thomas and Andrews, 1794), p. xv.

${ }^{4}$ New-England Psalm-Singer, p. 18.

${ }^{5}$ The Stoughton Musical Society's Centennial Collection of Sacred Music (Boston: Ditson, [1878]), p. 4.
} 
seems ironic because of the composer's obvious fascination with the bass line. In the New-England Psalm-Singer he frequently divided the bass in octaves, the lower part extending to Great $\mathbf{C}$ on occasion. Of the twenty basses in his ideal chorus, he recommends:

. . . six or seven of the deepest Voices should sing the Ground Bass, which I have set to most of the Tunes in the following Work, and have taken Care to set it chiefly in the compass of the Human Voice, which if well sung together with the upper Parts, is most Majestic, and so exceeding Grand as to cause the Floor to tremble, ${ }^{*}$ as I myself have often experienced. [Billings' footnote:] All Notes that descend below G Gamut in the Bass, occasion an agreeable Tremor. But in my Opinion double D, viz. (an Octave below the Middle Line of the Bass) is the most commanding and Majestick of any Sound in Nature. N.B. Blowing a Note carries it an Octave below itself, so as to make D blow'd ąs low as double D not blow'd, \&c. 6

In later collections the so-called Ground Bass, while still present on occasion, is less in evidence. So enamored of the quality of the bass voice was Billings that he claimed in the Singing Master's Assistant that most good singers were basses: "I think we ought to take a grateful notice, that the Author of Harmony has so curiously constructed our Organs, that there are about three or four deep voices suitable for the Bass to one for the upper parts, which is about the proportion required in the laws of Harmony." 7 The claim here is not that there is a preponderance of basses. Rather, according to Billings, people with good voices are three or four times more likely to be singers of bass than of any upper part.

If one takes all of this figuratively rather than literally-Billings as a writer, after all, is figurative-as a plea for a solid and audible bass-line and a relaxed vocal production in upper voices, it makes sense. In singing schools where the students were mostly youngsters, the number of mature bass voices would have been small and the bass overbalanced. Billings' students surely were no less likely to force high notes than are inexperienced singers today. It does not take a great deal of imagination to conclude that a forced high note from an uncultivated eighteenth-century throat probably sounded worse than anything that might be produced in the name of serious music today. The combination of training, sophistication, and self-consciousness that present-day singers share, in contrast to the inner-directed earnestness of some of their inexperienced forbearers, ensures that the modern choral director rarely will be forced to cope with the caterwauling of which Billings occasionally complained. "Few voices," he wrote, "but what want restraining, or softening upon high notes, to take off the harshness, which is as disagreeable to a delicate ear, as a wire-edged raisor to a tender face, or a smoaky House to tender eyes." 8 In his most specific advocacy of relaxed vocal production, he advised:

${ }^{6}$ New-England Psalm-Singer, p. 18.

7 Billings, Singing Master's Assistant (Boston: Draper and Folsom, 1778), pp. 14-15.

${ }^{8}$ Singing Master's Assistant, p. 15. 
Sing that part which gives you least pain, otherwise you make it a toil, instead of pleasure; for if you attempt to sing a part which is (almost or quite) out of your reach, it is not only very laborious to the performer; but often very disagreeable to the hearer, by reason of many wry faces and uncouth postures, which rather resemble a person in extreme pain, than one who is supposed to be pleasantly employed. 9

For the modern choral director who performs Billings, instinct and common sense will play a major role in the director's decisions, but these should not operate unchecked. A firm bass-line is essential, and there is precedent for doubling the bass if need be with instruments such as the cello or organ. Tenors and sopranos should be divided so that at times the six-voice texture described by Billings prevails. The strongest tenor voices should be retained for the tenor part since it is the main melody, and can be doubled with a group of lighter soprano voices. Likewise, a few tenors can be assigned to the soprano. The goal of the tenorsoprano doublings is a disposition in which the parts are equally audible when sung naturally and easily. The presence of a few sopranos on the tenor melody rescues the line from the middle of the texture. Conductors should not shy away from changing voice dispositions during pieces. One verse of a plain-tune, for example, might be sung in four parts and another in six. Though Billings remained silent on the subject, doublings would seem best set aside during sections for one or two voices in anthems and set-pieces. Octave doublings may safely be restricted to tenor and soprano; neither Billings nor any other musician of the period advocated the same thing for bass or counter.

Perhaps the most difficult aspect of performing eighteenth-century American music is matching the vocal production. Billings never described in detail the vocal quality he favored, and even if he had, it is doubtful that it could be interpreted today in terms specific enough to be useful to performers. Nasal singing was apparently widespread in the eighteenth century, and the composer's most direct comment on voice production warns: "Be sure not to force the Sound thro' your Nose; but warble the Notes in your Throat."10

The nineteenth-century Italianate resonance that results from modern vocal training is out of place in performing Billings. Perhaps the best guide for the conductor to consult is the recorded repertory of Southern shape-note singers. The shape-note tradition is, of course, chronologically and geographically far removed from eighteenth-century New England and cannot be taken as an authentic replica of the style of Billings' time. Yet, the Sacred Harp singers, for example, sing in a way almost entirely unfamiliar to ears accustomed to Brahms or the microphone-geared voices of popular musicians. Their tone is straight-or vibrato is at least involuntary rather than cultivated-and nasal, their dynamic range small, and they convey a sense of flexibility and ease. ${ }^{11}$

\footnotetext{
${ }^{9}$ Singing Master's Assistant, p. 14.

${ }^{10}$ Singing Master's Assistant, p. 13.

"Sacred Harp recordings are distributed by the Sacred Harp Publishing Co., Haleyville, Alabama. Recordings of twentieth-century Southern shape-note singers are
} 
The question of vocal production leads inevitably to a consideration of dynamics. Billings' specific dynamic markings were few, and they usually occurred in long pieces. Shorter tunes customarily were unmarked. It was one of the composer's chief axioms, however, that the music conform to the expressive content of the words. He used dynamics to reinforce textural moods; softer levels generally associated with minor-mode tunes and dolorous texts, louder ones with texts expressing triumph and joy. Performers, then, can take their dynamic cues from Billings' texts. The dynamics of solo passages, however, are not quite so obvious. In the New-England Psalm-Singer Billings advises: "Much Caution should be used in singing a Solo, in my Opinion Two or Three at most are enough to sing it well, it should be sung as Soft as an Eccho, in order to keep the Hearers in an agreeable Suspense till all the Parts join together in a full Chorus, as smart and strong as possible."12 The textural change manifest in solo passages must be supported by a lighter vocal quality. Billings made one more point about dynamics that present-day performers should note: voices should enter strongly after rests, "because that gives the Audience to understand another part is added, which perhaps they would not be so sensible of, if you struck in soft." This advice applies especially to "fuging Music," where, he insists, "you must be very distinct and emphatic, not only in the Tune, but in the pronunciation." 13

A large assortment of tunebooks was published in America during the latter part of the eighteenth century. This indicates that the controversy that earlier had raged through New England over whether to maintain an embellished oral practice or to sing from notation was resolved in favor of the latter. Yet, as Billings' and virtually every other tunebook of the time demonstrate, singers continued to ornament psalm-tunes. Ornaments were described in Billings' collections, and some advice on their application was given. The composer's recommendation on the use of embellishments, or "graces," was generally cautious, but he did admit to a fondness for their judicious use. Ornamentation of earlier music poses one of the greatest challenges a performer can accept. Eighteenthcentury psalm singers surely performed their ornaments spontaneously, probably according to the formulas that appear in book after book. Modern-day performers are not advised to follow suit unless they achieve an intimacy with the style that makes the ornaments a fresh overlay, rather than a studied alteration of the musical surface.

There may be choral directors who wish to encourage their singers to develop the skill of ornamentation by embellishing Billings' music, at least to introduce them to this dimension of performance practice. Conductors willing to experiment might begin by having the singers collectively embellish a psalm-tune, using the basic ornaments mentioned in the Singing Master's Assistant-the "grace of transition" and the single

also available from Folkways in New York, and in the Library of Congress folk music recording series.

${ }^{12}$ New-England Psalm-Singer, p. 18.

13 Singing Master's Assistant, p. 13. 


\section{4/JRME}

and double trill. Once they are accustomed to singing together certain standard ornaments, the conductor can decide for himself whether he wants to encourage individual singers to decorate at will. The act of decorating or creating one's own line on the spot is a requirement of some modern choral music, a need that many choral singers find difficult to meet for lack of experience. Whether the addition of improvised ornaments would bring the music closer to its original sound seems a moot point here. What does seem assured is that use of ornaments would bring the singers into closer psychological proximity with their eighteenthcentury counterparts.

Conductors also might want to experiment with another aspect of performance that has its precedents in eighteenth-century America. American colonial churches were sometimes built with narrow balconies across the back and extending part-way up either side. Choir-members stood on these balconies when they sang. Rather than a group massed tightly together, an eighteenth-century American choir was more apt to be a line of singers arranged around a rather large, open space. The singers were disadvantaged because they had more difficulty hearing each other and were surely less precise than if they had drawn more closely together. However, the separation of the singers helped to accentuate the independence of each line. In compositions employing textural changesthe solo or duet passages in anthems and set-pieces and in fuging-tunesthe singers' different locations in space would have made the contrasts especially arresting. The modern choral conductor probably will find himself in few situations that actually simulate the physical arrangement of the colonial church. But he will find that arranging his singers around the edges of as large a space as possible will help to make the linear dimension of Billings' music more easily audible, surely its greatest strength.

Colonial churches, with their high ceilings and bare wooden walls, offered a resonance that magnified the sound of Billings' music in a way impossible to duplicate in most modern buildings. A fuging-tune sung in its original surroundings must indeed have fit the composer's description of the genre as an "ocean of harmony" and "musical warfare."14 Less obvious in a modern acoustical setting is the subtle effectiveness of a piece like David's Lamentation. Without employing imitation in this somber little work, Billings achieved variety through textural contrasts. The full chorus is answered first by a unison, then by two-part writing before the four-voice conclusion. In a modern building the piece is so simple as to seem almost innocuous. Sung in the resonant atmosphere of a colonial church, the textural changes become glowing sound events that effectively reinforce the brooding mood of the text.

Billings' various theoretical introductions demonstrate the importance he assigned to tempo. In all three of his major essays on music-the introductions to the New-England Psalm-Singer, the Singing Master's Assistant, and the Continental Harmony-he explained how to construct pendu-

\footnotetext{
14 Continental Harmony, p. xxviii.
} 
lums to register the exact pace intended for each of his compositions. In eighteenth-century music generally, time signatures retained some of their earlier significance as indicators of tempo as well as meter. Proportional time signatures date back to the Renaissance, where they were always linked to a kind of standard tempo giusto, the tactus, geared to some basic biological fact such as a normal human heartbeat. The ratios they expressed had significance only in relation to the tactus. By the beginning of the nineteenth century, the notion of the time signature as tempo indicator had eroded. Its function since the early 1800 s has been to establish the meter and to govern the relationships between note values within that meter, with tempo specified by words like adagio, allegro, and so forth. In 1793, Andrew Law made a point of divesting time signature from tempo by encouraging consistent use of verbal tempo indications. However, it is no surprise that Law's suggestion was ignored by many compilers, and that time signatures continued to carry tempo significance well into the nineteenth century.

There is no question that Billings used time signatures to indicate tempo. In the New-England Psalm-Singer, after specifying the length of pendulums that would supply the proper beat for various meters, he added:

Notwithstanding the exactness of these Rules for keeping Time, yet Authors are sometimes arbitrary in quickening or slackening the Time, by inserting Musical Phrases over particuar Strains, such as Adagio, Slow, Grave, \&c. Either of these signify that Strain to be performed somewhat Slower than the Mood it is set to: So likewise when you see Allegro, Vivace, Presto, \&c. over any particular Strain, it implies that it must be performed something quicker than the Mood that is fixed to it; but when nothing of this Nature occurs, then observe strictly the Rules beforementioned. ${ }^{15}$

Thus, present-day performers of Billings' music should set their tempos from the time signature and should treat the rare verbal tempo indications he suggests as modifications of the pace implicit in the meter, rather than as absolutes.

The utility of Billings' pendulums remains somewhat puzzling. The problem is not accuracy or ambiguity, for the description could hardly be more specific:

And here it may not be amiss to inform you, how the length of pendulums are calculated; take this instance, suppose a Pendulum of thirty-nine inches and two tenths, will vibrate in the time of a second, then divide $392 / 10$ by four, and it will give you the length of a pendulum that will vibrate twice as quick; and multiply $392 / 10$ by 4 , and it will give the length of a pendulum that will vibrate twice as slow. 16

From Billings' descriptions, present-day scholars such as Allen Britton and Hans Nathan have compiled tables providing metronomic equiva-

\footnotetext{
15 New-England Psalm-Singer, p. 15.

16 Continental Harmony, p. vii. The same note also appears in Singing Master's Assistant, p. 8.
} 


\section{6/JRME}

lents for the durations of the composer's many pendulums' swings. Billings' nine "moods" of time are translated metronomically in Table 1. The pendulums' precise practical use remains a matter for some speculation. Perhaps singing masters and musical society conductors followed the pendulum in rehearsals while the choristers in turn followed their beat. When Billings describes how to make a pendulum he stresses the importance of its easy visibility, which seems to recommend its use with groups of singers. "Make a pendulum of common thread well waxed, and instead of a bullet take a piece of heavy wood turned perfectly round, about the bigness of a pullet's egg, and rub them over, either with chalk, paint or white-wash, so that they may be seen plainly by candlelight."17 Elsewhere, when he is enumerating various manifestations of what he calls "good time" in music, he writes: "Another good division is, when the performers move in exact conformity to the vibration of a pendulum. N.B. . . . to carry this military idea still further, you may consider the single bars in the stead of file leaders, and the pendulum in the place of the standard."18

Table 1

Tempo in William Billings' Music

\begin{tabular}{lcl}
\hline Term & Symbol & $\begin{array}{c}\text { Metronome } \\
\text { Equivalent }\end{array}$ \\
\hline Adagio & $\mathrm{C}$ & $d=60$ \\
Largo & $\varnothing$ & $d=80$ \\
Allegro & $\not \partial$ & $d=60$ \\
& $2 / 4$ & $d=120$ \\
& $3 / 2$ & $d=60$ \\
& $3 / 4$ & $d=80$ \\
& $3 / 8$ & $d=53$ \\
& $6 / 4$ & $d .=80$ or 60 \\
& $6 / 8$ & $j .=80$ \\
\hline
\end{tabular}

Virtually everything Billings wrote about tempo indicated that he believed firmly in metronomic strictness. Like many other singing masters and compilers, he advocated that singing-school scholars beat time with their hand or foot while singing. Perhaps Billings tried to sharpen his singers' sense of tempo by sometimes having them adjust their timebeating to the pendulum without his intervention. Used in this way the pendulum could become a coordinating agent that, in contrast to the singing master's customary domination of the class, silently demanded the scholars' concentration. Another difficulty with Billings' pendulums is that he allowed inconsistencies to compensate to some degree the precision of his measurements. For example, he assigned to the tempo indication "Largo" three different values.

\footnotetext{
${ }^{17}$ Continental Harmony, p. vii. The same note also appears in Singing Master's Assistant, p. 8.

${ }^{18}$ Continental Harmony, p. xixn.
} 
Billings' instructions on tempo remain immensely valuable, even though marked with occasional inconsistencies. His instructions provide a rather precise set of guidelines modern conductors would do well to follow. The twentieth-century performer of Billings' music is, in fact, put on his mettle by the very discrepancies that crop up in Billings' discussion. Performers are best advised to ponder what Billings has said, to distinguish the wheat from the chaff, and to allow what remains to govern their performances. The main impulse behind Billings' music seems to be declamation and the momentum that metrical declamation can generate. There is evidence that Billings sought in his performances to generate momentum through strict maintenance of tempo.

Present-day musicians who look at Billings' tunebooks will notice that, in almost all cases, only a single verse of text appears with the psalm and hymn tunes. In the New-England Psalm-Singer, texts are included only when they are not available in standard sources. Thereafter Billings underlays his music with at least one verse of text, and he is quite careful to provide the text source as well. The presence of only a single verse of text has created a problem for twentieth-century performers of Billings' music. For all their charm, single-verse psalm-tunes are too short to be church anthems or anything more than one of a group on a choral concert. Most likely the difficulty has been an editorial one. Modern-day editors of eighteenth-century American psalmody have remained puzzled over whether psalm tunes and hymn tunes were in fact strophic pieces to which several stanzas were sung, or whether they were performed exactly as written. Since editors generally have not provided additional verses, the psalm tune has remained a remarkably short-winded genre.

While some tunes obviously were composed with a certain text in mind and might not go with later verses of the same psalm or hymn, most of the psalm and hymn tunes of Billings and his contemporaries were sung strophically, with several verses of text. One reason Billings and other compilers as well are careful to mention their text sources is for reference, to enable singers to track down later verses in their psalters. Billings' Suffolk Harmony (Boston: John Norman, 1786) seems not to have been a commercial success. Surely part of the reason is that the texts he set there were not in common circulation, and singers were left with only a single stanza of text to sing. Further support for multiverse performance is found in American compilers' inclusion in their works of unfamiliar texts in several verses. Billings began the New-England Psalm-Singer with a three-stanza hymn by Mather Byles, which faces "America," the tune to which it is sung. In the Singing Master's.Assistant, "Aurora" is faced by a six-stanza hymn. Other compilers-Andrew Law, Simeon Jocelyn, Oliver Brownson, and Andrew Adgate-included in their collections hymns to be sung to certain tunes in the books, all in several stanzas. ${ }^{19}$

${ }^{19}$ Andrew Law, Select Harmony ([Chesire: William Law], 1779); Simeon Jocelyn and Amos Doolittle, Chorister's Companion (New Haven: for S. Jocelyn and A. Doolittle, 1782); Oliver Brownson, Select Harmony (n.p., 1783); and Andrew Adgate, Philadelphia Harmony' (Philadelphia: J. M'Culloch, 1789). 
One of the most perplexing questions about the performance of Billings' music is the matter of accompaniment. Only two of his compositions specifically call for accompaniment by instruments. "Peace. An Anthem," presumably composed in 1783, begins with a "symphony" composed for four unspecified instruments; brief contrasting interludes recur throughout the work. Billings inserted a footnote: "Symphony is sounds without words intended for instruments." The ordination anthem, "O thou to whom all creatures bow," published in the Continental Harmony, contains a pair of brief interludes written in two parts for unnamed instruments. Instrumental accompaniment was not necessarily rare; several works probably were intended for voices with instrumental accompaniment throughout. However, in the history of music the use of instruments in Christian churches has been a subject of intense and repeated controversy. New England in the eighteenth century was the center of such a controversy. Murray Barbour wrote in his study of Billings: "Since . . . no Congregational meeting-houses in Boston had organs at Billings' time, the need for an organ part would have been slight." 20 The matter is more complicated than that, however. To suggest how instruments might be used with present-day performances of Billings' music, it will be helpful to offer a glimpse of the controversy.

Puritan opposition to instrumental music in worship, established by John Calvin, remained canon in the colonies well into the eighteenth century. In 1764 the Rev. East Apthorp, in his Of Sacred Poetry and Music, refuted the grounds traditionally set forth by Congregationalists to oppose the organ. Apthorp cited New Testament authority for the acceptance of instrumental music in church by referring the congregation to Ephesians 5:19: "Singing and making melody in your hearts to the Lord." According to Apthorp's interpretation, "The words psallo used in this text, properly signifies to sing to an instrument; and is appropriated rather to the striking of chords, as in the lute or harp, than to the accompaniment of the voice." 21

Within the decade a New England edition of an anonymous pamphlet was published on the subject of using instrumental music in church. First issued in Philadelphia in the early 1760s, the pamphlet's lengthy title summarizes its point of view: The Lawfulness, Excellency and Advantage of Instrumental Musick in the Publick Worship of GOD, urg'd and enforc'd from Scripture ... Addressed to all . . . who have hitherto been taught to look upon the Use of Instrumental Musick in the Worship of GOD as unlawful. By a Presbyterian.22 Apthorp's discourse and this pamphlet offered well-reasoned appeals to the intransigence of New England Congregationalists to give way. Both works established as well that opposition to the organ was declining among British Calvinists and

\footnotetext{
${ }^{20}$ Murray Barbour, The Church Music of William Billings (East Lansing: Michigan State University Press, 1960), p. xv.

${ }^{21}$ East Apthorp, Of Sacred Poetry and Music. A Discourse at Christ-Church, Cambridge, at the Opening of the Organ (Boston: Green and Russell, 1764), p. 6.

${ }^{22}$ From an advertisement in the Essex Gazette, August 13, 1771, cited in Henry $M$. Brooks, Olden-Time Music (Boston: Ticknor, 1888), p. 72.
} 
among their Presbyterian neighbors. Perhaps the Revolutionary War helped to make the issue seem less than cosmic in importance. For soon after the conflict had ended, Boston Congregational churches began to install organs. Opposition remained both among clergy and laity, but by 1790 two of the leading Congregational churches in the city had pipe organs in their sanctuaries.

By 1774 the First Congregational Church in Providence, in which Billings taught that year, had a pipe organ. Billings' compositions of the period suggest nothing more than a capella writing. But his approval of the organ is documented in the introduction of the Singing Master's Assistant (1778), where he defines a voluntary as "an Air which is played on an Organ ... performed in Church before service begins, to soothe the minds and calm the passions of the Audience, for the fit worship of God." ${ }^{23}$ In the same work he describes the organ as "the grandest of all Musical Instruments," and gives evidence of its practical as well as aesthetic advantages. During the 1780s Billings' interest in the organ shifted from admiration of it as a peripheral phenomenon to acceptance of it in his own music. In 1782 Samuel Parker proposed commissioning Billings to compose an anthem "assisted by as many stops on the Organ as would immitate a soft and delicate Lyre . . . The two last verses, the organ to be thrown open." 24 Though this project came to nothing, the following year saw the appearance of "Peace. An Anthem," with its introductory "symphony" and its interludes. ${ }^{25}$ Though written, like choral music, on four staves, the "symphony" is almost exclusively in two-voice texture and easily could be read at sight by any organist.

The most decisive link between Billings and the organ can be traced to March of 1857, when Boston's First Church introduced an organ into public worship. Billings composed an anthem with organ to celebrate the occasion. The organ had been installed only after considerable struggle and even then with only the reluctant approval of the church's aged minister, Dr. Charles Chauncey. For those who had overcome their religious scruples against the organ, however, the occasion seems to have been a resounding success. The organ soon made itself indispensable at First Church in Boston. Thus, Billings worked at a church with an organ during the years $1785-1786$. It is unlikely that his use of the organ was restricted to that one single anthem, but the written record carries nothing beyond that one fact on the subject. Moreover, the composition Billings wrote for the event at First Church-a setting of Psalm 122-is not included in any of his tunebooks, seems not to have been published separately, and has not surviver.

The modern-day conductor of Billings is thus left with a knowledge that the composer liked the organ and wrote on occasion for organ and chorus. However, there are almost no examples of how to employ the organ in performances of Billings' music. The best that can be sug-

\footnotetext{
${ }^{23}$ Singing Master's Assistant, p. 27.

${ }^{24}$ Mather Byles, Letter Book, December 14, 1782 (New England Genealogical Society) .

${ }^{25}$ The only known copy of this work is in the Brown University Library.
} 
gested is a set of six guidelines within which to work. Firstly, if an organ is available, there is no need to avoid using it for fear of being inauthentic. Secondly, the principal role of the organ should be to reinforce the lines written by Billings, rather than to add anything new. The organ will be particularly effective in supporting dynamic changes Billings calls for in anthems and set-pieces, or in changes in volume the conductor might want to introduce between verses in shorter pieces. In view of Billings' expressed fondness for an audible bass, the third recommendation would be that the organist double the bass line when need be. Organ doubling also should help to bring out the melody if it is weak, or any other voice parts that need added support. The fourth guideline is that the organist should play from the choral score or from a keyboard reduction of that score. He should not use the bass-line as a continuo part to be realized as from a figured bass, for the harmonies that result will surely clash with what the upper voices are singing. When accompanying solo parts, the organist should add no harmonies but should stick to doubling. Fifthly, an organist with a thorough knowledge of the style might be encouraged to interpolate occasional brief interludes between sections of larger pieces, just as Billings composed in the two surviving works with instrumental indications. Finally, a conductor who has a chorus that is capable of an unaccompanied performance of Billings that satisfies him, should not introduce the organ for the sake of authenticity.

Instruments other than the organ sometimes were used to accompany psalmody, especially after the turn of the century. The cost of pipe organs often precluded their use in less affluent Congregational churches, but other instruments were also used to accompany the choir. Bass viols and clarinets were particular favorites. No documents have survived to link the so-called "gallery orchestra" with performances of Billings' music in his own time. However, there is no reason that modern performances should not employ a small group of that type to serve the functions outlined above for the organ.

Billings' music was written for people with less musical experience and skill than most of the singers who perform his music today. The goal of the modern conductor should be to try to reassert as many of the original ground rules of eighteenth-century American musical performance as he can without condescension toward the music and its humble origins. Certain techniques are to be avoided: tempos very fast or very slow, the assigning of the melody solely to the sopranos, correcting the sometimes awkward dissonances and unusual harmonic progressions Billings was apt to write, the encouragement of a cultivated bel canto vocal quality. Apart from these caveats, the conductor is urged to bend his instincts and energies within the guidelines suggested toward a high calling of translating William Billings' printed music into sound. ${ }^{26}$

The University of Michigan

Ann Arbor, Michigan

Worcester Polytechnic Institute

Worcester, Massachusetts

${ }^{20}$ This article was adapted from William Billings of Boston: Eighteenth-Century American Composer by David P. McKay and Richard Crawford, to be published in 1974 by Princeton University Press. 